ROCZNIKI HUMANISTYCZNE

Volume 66, issue $2-2018$

SELECTED PAPERS IN ENGLISH

DOI: http://dx.doi.org/10.18290/rh.2018.66.2-6se

GRZEGORZ BUJAK

\title{
DECANAL CONFERENCES OF PRIESTS \\ IN THE DIOCESE OF KIELCE \\ IN INTERWAR POLAND
}

In the interwar period, the network of deaneries still played an important role in church administration, outlining the scope of conduct for priests who undertook joint actions in the area. It was not a system of self-government because this was not provided for by church law. However, within the framework of church legislation and taking into account the regional conditioning and local traditions, the decanal structures have played an important role in the adaptation of the bishops' pastoral visions to the local needs and possibilities, which were implemented with the support of central diocesan institutions. As a result of these activities, a specific type of administration and pastoral care emerged in particular regions, the effects of which sometimes continue to this day. It was the outcome, on the one hand, of visions and programmes created by church authorities and central institutions, developing and evolving in the dynamically growing reborn Poland, and, on the other, the greatly diverse needs and capabilities of parish environments.

Having regained its independence, Poland saw opportunities for the clergy to develop both pastoral and social activities on a wider scale. It was quickly realised that improvements needed by the rural areas had to be introduced at higher levels than just parishes. As early as in 1917-1918, the renewed periodical Przeglad Diecezjalny published numerous articles emphasizing the significance of communication among the clergy for the coordination of especially pastoral and social activities.

Rev. Dr GrZegorz BujaK is an assistant professor of the Department of History of Polish Political System and Administration of the John Paul II Catholic University of Lublin (KUL); address: Al. Racławickie 14, 20-950 Lublin, Poland; e-mail: gbujak@kul.lublin.pl

The Polish version of the article was published in Roczniki Humanistyczne vol. 57, issue 2 (2009). 
In the article "Potrzeba czasu" published in 1918, an anonymous author signed as X.W.Z. wrote:

I think it advisable that the clergy of neighbouring parishes hold pastoral meetings, from one deanery at most, counting ten parishes, and as often as possible. The main purpose of these meetings is to discuss the moral diseases afflicting a given area and to devise remedies. ${ }^{1}$

In 1919, another article appeared in this journal, emphasizing the role of the decanal conferences in the achievement of the Church's mission. The author recalled the history of the conference. He pointed out that various unions and associations, including the enemies of the Church, met in order to establish the principles of joint activities, while the opposite was happening in the Church in Poland. While drawing a panorama of the great pastoral tasks the Church was faced with, he argued:

The task is grand yet dangerous. It cannot be attained if we act unaided; we must gather and debate, we must organize decanal conferences, both frequently and effectively, since they will make our religious and social work much easier for us. We must convene decanal conferences often because in them we shall determine the uniformity of our action. [...] We will avoid divisions or discord, and we will reach unity in our business if we care for frequent decanal conferences. It is not enough to organize them four times a year, as prescribed by the Church, they need to be organized very often, once a month, and even more often regarding more important matters. ${ }^{2}$

Decanal conferences of the clergy were not a new phenomenon in the Church in Poland. ${ }^{3}$ The Diocese of Kielce also had that tradition. Their importance was emphasized by Bishop Tomasz Teofil Kuliński in an instruction issued on 18/31 March 1906. The ordinary appreciated the importance of the conferences especially as a way of developing the spiritual life of the clergy. That is why he assigned a lot of importance to formative and ascetic matters, various religious services and confession to be discussed in such meetings. The conventions held at that time also played an important role in the system of supervision of the life and activity of the clergy. This inquisitorial function was given particular emphasis by Bishop Kuliński in

\footnotetext{
${ }^{1}$ Wincenty ZamoJski, "Potrzeba czasu," Przeglad Diecezjalny [renamed as Kielecki Przeglą Diecezjalny in 1925, henceforth abbreviated as KPD] 5 (1917-1918): 12-13.

2 "Sprawozdanie z ogólnego zebrania członków Stowarzyszenia Wzajemnej Pomocy Kapłanów Diecezji Kieleckiej,” KPD 6 (1919): 155.

${ }^{3}$ Stanisław WysockI, O kongregacjach dekanalnych w dawnej Polsce (Lwów, 1909), 5-11.
} 
a separate instruction. The crucial moment of the meeting was to inform the dean about the misdeeds of priests. To maintain secrecy, the dean was obliged to interrogate each priest separately. In minor matters, he was to take the appropriate decisions himself. However, in the case of graver crimes, such as those contra coelibatum, he was to inform the bishop immediately. During the conference, the dean was also to test the priests' readiness for the ad probandam exams. ${ }^{4}$

However, it was only when conditions for the Church's free activity were established at the end of the First World War and in the era of the Second Polish Republic that decanal conferences could fully develop and become an important form of the clergy's joint activity. They were not only discussion or opinion-forming forums but also venues for decision-making within the scope of the law of the Church.

The legal situation of decanal conferences was regulated by general church regulations and diocesan legislation. The Code of Canon Law of 1917 prescribed that a clergy conference be held in a bishop's city as well as in individual deaneries on days designated by the bishop. It also prescribed that such conferences be attended by of all the clergy exercising the cura animarum, and others if so ordered by the bishop. ${ }^{5}$

At a meeting of deans held in Kielce on 4 April 1918, priests in all deaneries were obliged to organize conferences at least three times a year and all priests were obliged to participate in them. The topics for discussion were to be sent by the Consistory, but the possibility of discussing local issues chosen by the priests was also available. ${ }^{6}$ The frequency of conferences in the initial period was not very regular and the participation of clergy was not very common. There were, however, deaneries where the importance of this form of activity was appreciated. This concerned mainly the area of Zagłębie Dąbrowskie [the Dąbrowa Coal Basin, Lesser Poland], where priests in 1918 passed a resolution to hold conferences on a monthly basis. ${ }^{7}$

In 1926, by the bishop's decision, a certain framework was imposed on the pastoral conferences of priests working in Kielce. It was now required

\footnotetext{
${ }^{4}$ Diocesan ARChIVE In KIElCE [henceforth abbreviated as DAK]. Okólniki Biskupa, Konsystorza i Kurii, file ref. no. OA 2/11, sheets 29-33; see Daniel OLSZEWSKI, "Funkcje społeczno-kulturalne polskiej parafii na przełomie XIX i XX wieku," in Kulturotwórcza rola Kościoła na przełomie XIX i XX wieku, edited by Jan Ziółek (Lublin: Wydawnictwo KUL, 1997), 37.

${ }^{5}$ Codex iuris canonici Pii X pontificis maximi iussu digestus Benedicti Papae XV Auctoritate Promulgatus (Romae: Typis Polyglottis Vaticanis, 1917), 131, 448.

6 “Konferencja Księży Dziekanów,” KPD 5 (1917-1918): 248-249.

7 “Ogólne zebranie księży dekanatu będzińskiego,” KPD 5 (1917-1918): 157.
} 
that the meetings be held once a month except for three summer months. Not only priests doing pastoral work but also all the clergy of Kielce, including the Curia workers and the seminary lecturers, were to take part in the conferences. ${ }^{8}$

The diocesan synod of 1927 produced two documents devoted to decanal conferences. Statute 16 stipulated that the conferences be held three times a year in individual deaneries, and at least six times a year in the city of Kielce. The purpose of the decanal conferences was to increase the knowledge and devotion of the clergy. They were to discuss liturgical problems and moral issues, as well as any other matters chosen by the bishop. The date and programme of the conference was to be submitted to the Curia in advance, as well as a report after the conference. The statute highlights the importance of discussing the problems of priesthood and pastoral work, the proclamation of the Word of God, erecting church buildings and church-social issues. Not only theoretical discussions but also practical exercises in catechesis or preaching were permitted. The possibility of submitting miscellaneous matters was also catered for, and the decanal conferences also provided an opportunity to organise priesthood retreats. ${ }^{9}$

Details of conference organisation were regulated by the synodal instruction. Pursuant to canon $448 \S 1$ of the Code of Canon Law, the chairman of the conference was to be a dean. He was to inform all priests of the deanery about the date and subject of the meeting, nominating the speakers. All priests, both diocesan and religious, were obliged to participate in the conference. The conference was to be one day long. The dean was to appoint a secretary who would be obliged to record the course of the conference in a special book, which was to be filed in the deanery archives. The conference would have two parts. It was to start at 10 am with a church service and next the proper deliberations would take place in the presbytery. ${ }^{10}$

In the light of the surviving sources, it seems that the bishop's and synodal recommendations requiring regular decanal conferences were not fulfilled everywhere. For example, in 1930 the conferences were held only four times in Kielce, three times in twelve deaneries, and only once in two of them (the towns of Księżnice Wielkie and Daleszyce). ${ }^{11}$

\footnotetext{
8 “Do Wielebnego Duchowieństwa miasta Kielc," KPD 13 (1926): 170.

${ }^{9}$ Synodus Dioecesana Kielcensis 1927. Kielce [no publication year], 57.

${ }^{10}$ Ibid., 255-257.

${ }^{11}$ DAK, Konferencje Dekanalne, Dziekanów i Statystyki Kościelne, file ref. no. OD 2/2c, sheet 1.
} 
Still in 1926, Fr. Pilch was appointed diocesan director of pastoral conferences having a total supervision of them. The director was in charge of the thematic scope of papers to be presented in all conferences, collection and compilation of reports on particular deaneries, and presentation of priests' opinions contained therein to the bishop. ${ }^{12}$ In this way the model of decanal conferences was beginning to take shape, according to which the conferences were now regarded as an important tool for inspiring and organising the local clergy for the realization of tasks deemed important by the diocesan authorities. The discussion of the same topics in all parts of the diocese introduced discipline and order to the agenda, and the conference reports gave the bishop a picture of the clergy's views. Interpreted in this way, the conferences constituted a discussion of sorts taking place between the bishop and diocesan priests. They made it easier for the ordinary to develop pastoral programmes based on a broader understanding of their feasibility, expressed in discussions and conclusions produced by decanal conferences.

Recommended by the bishop and mediated by the director for pastoral conferences, the subject matter of papers to be delivered was varied and reflected the bishop's changing views on the most important pastoral goals in a given period. Thus, the 1918 consistory recommended that a discussion be held in all deaneries on the following topics: How to counteract the Bolshevik movement in the parish? How to heal the wounds of war inflicted on morals? How to deal with usurious rates, smuggling and taking things owned by others out of necessity? In the following year, however, in view of significant support given by the diocesan community to popular folk parties in the elections to the Sejm, the following issues were obligatorily discussed at the deanery level: i) What were the reasons that the Catholic people voted for socialist-folk deputies (discussion of the reasons for the choices made, priests' mistakes and mistakes made while campaigning)? ii) What is the way to rectify evil so that the people do not stray completely from the Catholic path? and iii) the continuing programme of pastoral work in the parish to maintain the dignity and authority (influence) of the priest on the people. ${ }^{13}$

The discussion of the issues indicated above was the imperative dictated by the time. Under standard procedure, however, the topics for all three decanal conferences were announced at the end of the previous year and published in Przeglad Diecezjalny. Each conference was to discuss two papers.

\footnotetext{
12 “Do Wielebnych Księży Dziekanów diecezji kieleckiej,” KPD 13 (1926): 169.

${ }^{13}$ DAK, Konferencje Dekanalne, Dziekanów i Statystyki Kościelne, file ref. no. OD 2/2a, sheets 8,14 .
} 
One of a socio-pastoral nature and the other, usually more theoretical, of a dogmatic or biblical character.

For example, in 1929, many conferences discussed a paper entitled "The biblical description of the Creation versus the modern sciences." In the following years these papers were discussed: "On the promotion of profounder religious life among youth" and "Children's Holy Communion." Also, the introduction of a new ritual for Polish dioceses, etc. was debated. ${ }^{14}$ The dominant social and pastoral subjects in the 1930s were the problems associated with the operation of Catholic Action. This demonstrated the importance which the diocesan authorities attached to the development of this organization. Many papers also addressed in detail specific issues of working with youth and the organisation of various Catholic youth associations.

Growing central supervision of decanal conferences had negative consequences, too. The subjects of the papers, often very theoretical and determined on a top-down basis, did not always address the local issues. This led to an increasingly formalistic treatment of the discussion of such issues, producing superficial conclusions. Given the above, having quickly conducted an obligatory analysis, the priests moved on to decanal matters related to the current pastoral issues.

Complete documentation of decanal conferences has not been preserved. It seems that not all the deaneries would regularly submit their conference reports and many of those were rather conventional. Not all of them were printed in full in the Przeglad Diecezjalny magazine. Its editors sometimes omitted, for various reasons, the relevant parts of the reports.

The conferences provided space for common principles for all parishes of the deanery to be established. Their objective was to unify pastoral and administrative practices in the neighbouring parishes and to agree on a common course of action in matters that required solidarity of the local clergy. For example, in 1918, the hours and manner of services were unified in the deaneries of Chmielnik and Zadroże. Common dates for the sacraments of baptism and marriage were set for the deaneries. The priests of the deanery of Pacanów applied to the diocesan authorities for the publication of the previously dispersed regulations on rosary services in a single brochure. In the deaneries of Zadroże and Olkusz, the issues of unifying the teaching of the Catechism and the topics of catechism sermons were considered, assuming slightly different solutions for the two neighbouring deaneries. ${ }^{15}$ In the

\footnotetext{
14 “Konferencje dekanalne,” KPD 16 (1929): 240-243.

15 “Obrady konferencji dekanalnych,” KPD 6 (1919): 41-42.
} 
following years, these issues were also discussed in other deaneries. ${ }^{16}$ The matters of religious observance continued to reappear at the decanal meetings, proving that the decisions taken within the decanal scope were not always implemented. In 1928, at the decanal conference in Pińczów, the priests once again underscored the need for punctual celebration of services and reliable preparation of sermons. ${ }^{17}$

In 1927, in the deanery of Słomnice, following the conclusions of a pastoral course organised in Kraków, a three-year cycle of lectures on the Catechism was pursued. A number of solutions common to the whole deanery were also introduced in the area of Sunday services. The duration of homilies was limited to 15 minutes and sermons to 30 minutes. $^{18}$

The decanal conferences also hosted theoretical discussions addressing the organization of parish ministry. The deaneries of Zagłębie Dąbrowskie were especially active in this respect, where attempts had been made as early as the 1920s to transfer the experience of the Church of Western Europe to Poland. Following the division of the diocese, this issue continued to be discussed by the priests of the deanery of Olkusz. For example, Fr. Pytlawski's paper on pastoral care in France and the opportunities to transpose those solutions to the diocese of Kielce was discussed in $1926 .{ }^{19}$ However, there is no evidence that these discussions had impact on the vision of the organization of parish life endorsed by the central diocesan institutions in Kielce. Discussions of this subject were resumed shortly before World War II during the term of the new ordinary, Bishop Czesław Kaczmarek, who unlike his predecessor was more eager to draw on the experience of the Western Church, which stemmed from his personal experience gained during his stay in Belgium. ${ }^{20}$

Within deaneries, the principles of spiritual direction were also established as well as the principles of confession and penance. These were important elements in the unification of pastoral ministry carried out in deaneries. For example, in 1930, in the Włoszczowa deanery, the issue of confession was discussed, mainly with respect to young people, paying attention to the waning sensitivity to certain sins. In order to counteract this trend, it was

\footnotetext{
16 “Konferencje dekanalne w roku 1931,” KPD 18 (1931): 238.

17 "Z konferencji dekanalnych," KPD 15 (1928): 29.

18 "Konferencje dekanalne," KPD 16 (1929): 272-273.

19 "Olkusz. Konferencja dekanalna," KPD 14 (1927): 27.

${ }^{20}$ Jan ŚLEDZIANOwSKI, Ksiadz Czesław Kaczmarek biskup kielecki 1895-1963 (Kielce: Jedność, 2008), 28-29, 56.
} 
decided to modify the topics addressed in retreat sermons for young people to make them made more sensitive to such issues. ${ }^{21}$ In the deanery of Irządze, still in 1927, the priests were instructed to develop a catalogue of penances which could be easily imposed in Easter confessions. ${ }^{22}$

At the turn of the 1930s, an initiative emerged to visit the parochial families in a time other than the Christmas visitation. This initiative was debated in several deaneries. In 1930, during the Pińczów conference the need for such additional pastoral visitation in the summer time was justified by Fr. Zając, who argued that

\footnotetext{
it is better to do visits in summer without neglecting the Christmas visitation. Visitation or the Christmas rounds should not only provide an opportunity to receive offerings but also to support the good, comfort the suffering, or admonish and punish addicts. After such a visit, several sermons can be given later, which are [the expression of - G.B.] cura animarum. $^{23}$
}

The same problem was considered in 1934 by priests at a meeting of the clergy of the deaneries of Kielce, Piekoszów and Daleszyce. ${ }^{24}$ However, these plans were not materialised.

Within the deaneries, attempts were made to solve mainly the local problems, such as the threat of the Polish National Church spreading in the area of the deanery of Bodzentyn, which was open to innovations penetrating from the diocese of Sandomierz. ${ }^{25}$ Priests were keen to discuss the causes of this phenomenon and methods of counteracting it. In 1930, in a discussion of the reasons for the rapid development of the National Church, it was stated that "the clergy, who in some parishes were not able to take a pastoral stand regarding their flock, were mostly to blame." The roots of the phenomenon were also sought in the low awareness and knowledge of Catholics:

Among the young, not to mention the older generation, there is a glaring dearth of information about the most fundamental religious truths [...]; this can be seen in the prenuptial examinations.

\footnotetext{
21 “Konferencje dekanalne w r. 1929,” KPD 17 (1930): 158.

22 "Konferencje dekanalne," KPD 14 (1927): 92.

23 "Konferencje dekanalne w roku 1934," KPD 22 (1935): 62.

24 “Konferencje dekanalne," KPD 21 (1934): 180.

${ }^{25}$ Edward WarchoŁ, Polski Narodowy Kościót Katolicki w Polsce (1922-1952) (Radom, “Ave," 1995), 301-305.
} 
In order to combat heresy, it was decided not to keep only to the teaching of the Catechism, preached periodically from the pulpit, but to use every opportunity to teach the faithful. ${ }^{26}$

It seems that all deaneries regularly discussed the problems of the organization of confessions during Advent and Lent confessions initiated by Bishop Augustyn Łosinski. These discussions produced proposals for structural solutions for all parishes in the deanery. Series of retreats or at least of special teachings on the same range of topics were proposed for all parishes. Sometimes, as in the deaneries of the powiat of Olkusz in 1933, priests were designated by name to deliver those lectures. Single parishes found missions to be a considerable financial and organizational problem. In some deaneries special funds were created for this purpose. In 1933, priests in the deanery of Sędziszów decided to allocate annually 40 zloty from each parish to this fund and support missions in consecutive parishes of the deanery with this amount. ${ }^{27} \mathrm{~A}$ similar fund was also created by priests in the deanery of Pinczów, who accepted a contribution of 3 zloty per month for this purpose. ${ }^{28}$

An important point on the agenda of the decanal conferences was the issue of fees for religious services, which would often give rise to disputes between the faithful and priests. In 1918, this issue was most often raised by the priests of the deanery of Włoszczowa. They tried to introduce relevant rules to be applicable in the whole deanery. However, this turned out to be unrealistic, especially with regard to funeral fees. At the same time, the clergy of the deaneries of Jędrzejów and Miechow called for the diocesan authorities to introduce systemic solutions regarding iura stolae in consultation with the state authorities. ${ }^{29}$

Although the synod held in 1927 adopted the solutions concerning the stole fees for the whole diocese, the issue continued to be discussed in the deaneries. Priests would often set intra-decanal iura stolae fees, which were lower than those permitted by the synod. This was the case, for example, in the deanery of Sułoszów, where in 1932, due to the economic crisis, a reduced rate applicable to the whole deanery was proposed by Fr. Jan Jędrychowski. ${ }^{30}$ In 1933, the priests of the deanery of Pinczów appointed a threeperson commission chaired by Fr. Wiśniewski in order to determine the

\footnotetext{
26 “Konferencje dekanalne w r. 1930," KPD 17 (1930): 282-284.

27 "Konferencje dekanalne w r. 1932," KPD 20 (1933): 39.

28 “Konferencje dekanalne w Kielcach," KPD 20 (1933): 44-45.

29 “Obrady konferencji dekanalnych w 1918," KPD 6 (1919): 43.

30 “Konferencje dekanalne w 1932,” KPD 19 (1932): 71.
} 
amount of iura stolae fees for the whole deanery, lower than the amounts prescribed by the synodal instruction. Their resolve was-as stated in the minutes - "not to give weapons to evil people." 31

At the decanal conferences, the question of overcharging for religious services - practised by some priests - was also discussed. For example, in Pińczów on 23 February 1938, the possibility of imposing a ban on the clergy was debated against charging higher fees than those provided for by the diocesan regulations. ${ }^{32}$ The problem of stole fees was not solved throughout the interwar period and was a major issue faced by all dioceses. ${ }^{33}$

At the deanery level, many problems related to cooperation among priests and the principles of coexistence among the clergy were attempted to be solved. It was proposed that a judge be appointed, typically the dean, who would settle possible disputes. ${ }^{34}$ Social initiatives were also launched. For example, in the deanery of Proszowice, the decanal fund was established to cover the costs of treatment of condecanal priests; also contributions, spending rules and an expenditure peer-control system were established. Within deaneries, there were also initiatives to benefit the local communities, which otherwise individual parishes could not afford. In the deanery of Małogoszcz, for example, it was decided to set up a day care facility, for which a suitable building was to be found, with the rent payable from the deanery's funds. Also, it was planned to bring nuns to manage the facility. ${ }^{35}$

Social issues were more often discussed in deaneries of urban character; initially the leading deanery was that of Zagłębie Dąbrowskie, but after the deanery was detached from the diocese in 1925 the conferences of Kielce priests. For example, a conference held in Kielce on 14 December 1927 discussed the influence of standard of living on the religiousness of workers. There, a decision was made to appeal to the directors of Kielce factories to improve the situation of their workers. A motion was tabled by Fr. Sonik to establish an inter-parish committee whose purpose would be to attempt to obtain long-term loans for cheap housing for the homeless of Kielce. ${ }^{36}$ However, the initiative was never to be launched due to the economic crisis, among other reasons.

31 "Konferencje pasterskie w Kielcach," KPD 20 (1933): 44.

${ }^{32}$ DAK, Konferencje Dekanalne, Dziekanów i Statystyki Kościelne, file ref. no. OD 2/5, sheet 40.

${ }^{33}$ Jerzy WisŁocKI, Uposażenie Kościoła i duchowieństwa katolickiego w Polsce 1918-1939 (Poznań: Wydawnictwo Uniwersytetu Adama Mickiewicza, 1981), 244-250.

34 “Obrady konferencji dekanalnych w 1918," KPD 6 (1919): 44.

35 "Konferencje dekanalne," KPD 15 (1928): 28-29.

36 “Kielce. Konferencja pasterska księży kieleckich,” KPD 15 (1928): 44. 
Social issues were also addressed by the decanal conferences of rural clergy, probably to a greater extent than it was evident from official records. The issue of agricultural reform was a dominant subject, as was the case, for example, in the decanal conference held in Proszowice in 1938. The attendees formulated an opinion published in "Kielecki Przegląd Diecezjalny." Its main arguments were: "A healthy agricultural reform is becoming a necessity, and also Catholic social activists should talk about it. Pastors are to, if need be, take a stand defending people working for their masters who were wronged by being sacked from their jobs in order to cut down on pension burden; these cases are used by the socialists to oppose the Church., ${ }^{, 37}$

A similar initiative was planned by some priests in the Diocese of Siedlce in 1936 and they wanted priests from other dioceses to join them. These plans were known to Bishop Łosiński, but he did not see the need for such an appeal. In a special circular, he discouraged the priests of the Kielce diocese from supporting the initiative launched by the Siedlce priests. ${ }^{38}$ No wonder, then, that any proposals regarding those matters, as was the case in the deanery of Proszowice mentioned above, could be officially formulated only after the ordinary's death.

At the decanal level, priests also formulated common positions regarding the secular authorities in the face of various problems. Most often, the issue at stake was their attitude towards decisions of the tax authorities. The largest number of disputes concerning that problem as well as the joint activities undertaken by priests within the scope of the deaneries are attested for the powiat of Pińczów. The controversies usually concerned the excessive taxes imposed on the clergy by the powiat authorities. Taking these cases to the Ministry of Religious Denominations and Public Literacy, the curia usually managed to moderate these disputes. ${ }^{39}$

It was often the case that priests of different deaneries took different decisions on the same matters, considering the local circumstances. These divergences were important for the curia since they demonstrated the diversity of opinions visible among priests and the possibilities the central government had. In 1932, the possibility of unifying textbooks for religious instruction was discussed. In the deanery of Skalbmierz, the priests approached

\footnotetext{
37 “Sprawozdanie z konferencji dekanalnych w r. 1937," KPD 25 (1938): 141.

${ }^{38}$ DAK, Akta Dziekańskie Ogólne, file ref. no. OD 4/2, sheets 85-87.

${ }^{39}$ DAK, Konferencje Dekanalne, Dziekanów i Statystyki Kościelne, file ref. no. OD 2/2c, sheet 4; DAK, Akta Dziekańskie Ogólne, file ref. no. OD 4/2, sheet 67; Akta Biskupa Augustyna Łosińskiego, file ref. no. B I 8/4, sheet 122; B I 8/5, sheets 198-200.
} 
these proposals with reserve. For the time being, they decided not to carry out unification in the deaneries due to the impoverishment of the population and the intended amendments to the curricula. On the other hand, the priests from the neighbouring deanery of Proszowice took a different approach to the matter, insisting on the rapid introduction of new textbooks. ${ }^{40}$

At the decanal conferences, critical remarks were sometimes formulated about the central administrative institutions of the diocese. This fact, however, was very rarely mentioned by official reports. Critical remarks were made about the diocesan curia. Too much lenience towards delegations of the faithful was criticised as those would come to the see in Kielce to make complaints about priests. The attendees argued that the curia took insufficient measures to defend priests and issued unjust decisions, often without consulting the priests concerned. ${ }^{41}$

In 1937, after the death of Bishop Łosiński, the priests of the deanery of Daleszyce formulated a position on the financial obligations due to the central diocesan institutions. The statement is preserved in the excerpts cited in the report from the conference of deans of 27 September 1937, who were in agreement with those postulates. The priests requested that they should be paid full salaries from the concordat grants, without any deductions. They proposed that the amounts and intended purposes of the contributions imposed on them by the central diocesan institutions were consulted with the decanal conferences and that the spending of such funds be supervised. ${ }^{42}$

\footnotetext{
40 "Konferencje dekanalne w roku 1931," KPD 18 (1931): 41-42.

${ }^{41}$ At the conference in Piekoszów held on 26 August 1926, this issue was raised by some priests. The resolution addressed to the ordinary reads: "as regards the aspects of the most sensitive issue, there have been several complaints in our deanery, and yet we must declare with all force that the «tax of the Diocese of Kielce» is the lowest of all the dioceses of Congress Poland and does not hold up to any more serious criticism in the times of ever increasing prices. Under such circumstances, with a view to protecting the already shaken authority of the Kielce curia and not very fortunately supported by it [emphasis-G. B.], it was resolved to follow its instructions as closely as possible in order to avoid bitter quarrels, provoked by people of bad will. If, however, despite the concessions, the bad will-directed by hostile campaigning against the clergy - were to refer dissatisfied petitioners to the splendid Curia, it was decided to request His Excellency to refer the petitioners to the Dean so that he might be informed about their case and check the legitimacy of the claims right away, and to settle the matter amicably out of regard for taxes and justice. For sometimes an ill-disposed petitioner amplifies facts and presents a distorted view, and the judgements of the Curia, issued unilaterally, discredit priests while giving people encouragement, deprive priest of the remainder of the authority he still has in the eyes of his parishioners" (DAK, Konferencje Dekanalne, Dziekanów i Statystyki Kościelne, ref. OD 2/ 2a, sheets 41-42).

${ }^{42}$ The following excerpts explaining the stand of the Daleszyce priests were quoted in the minutes of the conference: "a) The priests of the deanery, having regard to the increasing impov-
} 
The new ordinary, Czesław Kaczmarek announced a comprehensive solution to the income problems and the financial burden the priests carry towards the maintenance of central diocesan institutions. Until then, the existing financial model of the diocese was to remain in force. However, the war put an end to the reform, and the decanal conferences did not obtain the right to be consulted on the financial burden imposed on the clergy.

Issues that had been bothering all of the Polish clergy in the two decades between the wars were also discussed at the decanal level in the Diocese of Kielce, for example the issue of insurance encorced on the church staff (organists) and compulsory fire-protection contributions payable from the personal assets of priests. The dispute itself and its course are described in the relevant literature. ${ }^{43}$ In individual deaneries, priests submitted petitions to the diocesan and national church authorities requesting that the intensifying conflict be resolved. At the decanal conference in Słomniki in 1934, a petition was adopted to request the entire episcopate that "the most eminent Episcopate take into consideration the excessive burden that the parochial clergy bear on account of payments for health maintenance organisations, insurance for office workers, and fire insurance for churches-and devised a way to deal with these burdens." 44 Similar requests were submitted to the diocesan authorities by priests of other deaneries. Priests from the deanery of

erishment of the people, and the resultant decrease in their generosity and offerings for church services, and not wanting to adhere even to the minimum synodal norms for tactical reasons, declare their great wish that the salary to which they are entitled in full be paid to everyone's hands. We understand the needs of the diocese and we do not evade giving offerings, but the amount of offerings and their intended purposes should be approved in advance by the decanal conferences, so that each priest may have the natural satisfaction that he gives and that the purpose owes its existence to his generosity; b) Linked to this matter is another one, namely the inclusion of the public penny from the generosity of priests for diocesan purposes in strictly as an element of incomings and outgoings. The above is accompanied by our wish that a special financial commission be appointed with the Curia, as is has been the case with other dioceses, which would from time to time, at least once a year, provide the public with detailed reports with priests submitting their observations. Putting forward the above arguments, the priests of the Daleszyce deanery make themselves immune to the accusation of recklessness or anybody's criticism, or anything, but as mature people holding offices, they speak their mind, wishing that the great many problems which are often complained about, which unfortunately is sometimes divulged to the public, would change for the better, so that they could work willingly for the glory of God and the benefit of the Church in a quiet and peaceful atmosphere in submissive yet reasonable obedience to the spiritual authority" (DAK, Konferencje Dekanalne, Dziekanów i Statystyki Kościelne, file file ref. no. OD 2/ 3a-b, sheets 180-183).

${ }^{43}$ Jerzy WisŁOcKI, Uposażenie Kościoła, 300-301.

44 “Sprawozdanie z konferencji dekanalnych rok 1930,” KPD 18 (1931): 92. 
Sułoszów adopted a petition whereby they resolved to request the diocesan authorities "to defend priests against the enforcement of insurance contributions paid for church staff out of pastors' personal property, and to cancel any debt arising therefrom." In a similar spirit, the priests gathered at the decanal conference in Szczekociny put forward such claims. ${ }^{45}$ At the same time, in the deanery of Szczekocin, it was resolved to hold direct talks with Zakład Ubezpieczeń Społecznych [Social Insurance Institution]. The priests were not supposed to deal with the insurance company on their own and therefore delegations were sent to Kielce in order to negotiate the debt repayment terms for the whole deanery. ${ }^{46}$

Deaneries in Poland proved to be immensely efficient structures in the unification of priests in their opinions on important matters requiring the diocesan clergy to take a stand. This turned out to be particularly important whenever attacks on the ordinary launched by the legionary press, most intensely in 1921 and 1931 and after Józef Piłsudski's death. In such cases, declarations of support for the bishop were unanimously adopted in the deaneries. ${ }^{47}$

Importantly, decanal conferences paved the way for the diocesan synod. They were venues where draft statutes were discussed, often in the presence of representatives of the Curia and the Cathedral Chapter. Delegates were appointed for pre-synodal conferences in Kielce. In this way, the parish clergy were actively involved in the creation of diocesan law, which was to regulate the activities of the operation of the Church in the Kielce region for years to come.

Decanal structures also provided a lot of support for general diocesan organizations. This concerned not only secular social organizations, such as Catholic Action, or devotional organizations, such as living rosary circles, which had their own deanery directors and for which retreats, conventions and trainings were organized within particular deaneries. ${ }^{48}$ This also applied to the clergy organised in "Work" Union of Priests. Already in 1919, the Board of the union recommended the establishment of a separate circle in each deanery, ${ }^{49}$ and the rules of the union, published in 1920 , contained se-

\footnotetext{
45 “Konferencje dekanalne,” KPD 21 (1934): 149, 151.

${ }^{46}$ DAK, Akta Biskupa Augustyna Łosińskiego, file ref. no. B I , 8/3, sheets 182-200; "Konferencje dekanalne,” KPD 21 (1934): sheet 151.

47 “Konferencje dekanalne w roku 1931," KPD 18 (1931): 207; DAK, Akta Biskupa Augustyna Łosińskiego, file ref. no. B I 8/8, sheets 75-80, 91-92; B I 8/3, sheets 305-325.

48 "Sprawozdanie z czwartego dorocznego posiedzenia Rady Diecezjalnej Akcji Katolickiej w Kielcach," KPD 22 (1935): 49.

49 "Koła dekanalne "Praca"," KPD 6 (1919): 118.
} 
parate provisions governing the functioning of decanal rosary circles. ${ }^{50}$ The diocesan authorities lent such a great support for the movement that, in order to revive the union, they allowed the meetings to be held together with decanal conferences. However, that experiment failed. This did not revitalise the activity of the decanal "Work" groups, but undermined the esteem and standard of the decanal conferences. Finally, at the general assembly of the union, held in September 1924, it was decided to keep the union's meetings separate from decanal conferences. ${ }^{51}$

The decanal network provided a foothold for the organisation of the clergy's work on a larger scale. In the 1920s, inter-decanal conferences of the priests of Zagłębie Dąbrowskie were held. They discussed those pastoral and social issues which were important for the whole region. In 1931, a conference of priests of the three deaneries of the Olkusz powiat was held, devoted to the question of priests' attitude to associations of farmers. Ultimately, a resolution was adopted to hold an inter-decanal conference once a year in order to address matters specific to pastoral ministry within the powiat. ${ }^{52}$ However, we do not know whether the resolution was ever implemented. On the other hand, inter-decanal conventions of the clergy became a regular feature, supported by the diocesan authorities and devoted to the problems of religious instruction in schools. These were the so-called didactic and pedagogical conventions. They were organized for priests from a given powiat to discuss issues related to religious instruction give the local circumstances. ${ }^{53}$

Decanal conferences in the Diocese of Kielce during the interwar period became an important stage in the process of formulating the viewpoint of the parochial clergy, both in matters concerning the local pastoral ministry and those applicable to the diocese at large. For the bishop and the curia, they were but one important instruments for managing the diocese, forming the views of the clergy and gathering information about the life and views of both the priests and the faithful of the diocese. They contributed to greater culture of discussion and the ability of parochial clergy to cooperate with the central administrative institutions of the diocese.

\footnotetext{
50 “Regulamin działalności kół dekanalnych "Pracy”," KPD 7 (1920): 163-164.

51 "Sprawozdanie z walnego zebrania Związku Księży Diecezji Kieleckiej "Praca”," KPD 12 (1925): 18

52 "Konferencje dekanalne w r. 1931," KPD 18 (1931): 237.

${ }^{53}$ DAK, Konferencje Dekanalne, Dziekanów i Statystyki Kościelne, file ref. no. OD 2/2, sheet 119.
} 


\section{BIBLIOGRAPHY}

OLSZEWSKI, Daniel. "Funkcje społeczno-kulturalne polskiej parafii na przełomie XIX i XX wieku [The social and cultural functions of the Polish parish at the turn of the $20^{\text {th }}$ century]." In Kulturotwórcza rola Kościota na przetomie XIX $i$ XX wieku [The culture-forming role of the Church at the turn of the $20^{\text {th }}$ century], edited by J. Ziólek, 9-90. Lublin: Redakcja Wydawnictw KUL, 1997.

ŚledZIANOwsKi, Jan. Ksiadz Czesław Kaczmarek biskup kielecki 1895-1963 [Fr. Czesław Kaczmarek, the Bishop of Kielce 1895-1963]. Kielce, 2008.

Warcho€, Edward. Polski Narodowy Kościót Katolicki w Polsce (1922-1952) [The Polish National Catholic Church]. Radom: "Ave", 1995.

WisŁocKI, Jerzy. Uposażenie Kościoła i duchowieństwa katolickiego w Polsce 1918-1939 [The upkeep of the Church and Catholic clergy in Poland]. Poznań: Wydawnictwo Uniwersytetu Adama Mickiewicza, 1981.

Wysocki, Stanisław. O kongregacjach dekanalnych $w$ dawnej Polsce [On decanal congregations in Poland of the past]. Lwów, 1909.

\section{DECANAL CONFERENCES OF PRIESTS IN THE DIOCESE OF KIELCE IN INTERWAR POLAND}

\section{Summary}

After Poland regained independence the role of priests' deanery conferences gained more importance. Regular deanery conventions of the clergy positively influenced pastoral work, established order in it as well as unifying its goals and methods. They also played an important role in solving the problems of local priests concerning their living standards. The bishop appreciated the significance of deanery conferences, judging them to be an important element of the system of management and control of the diocese. In 1926, a diocesan director of pastoral conferences was appointed, his aim being, among others, to set subjects for discussion at such conventions. The conferences became an important instrument for finding out about priests' opinions and their attitudes as well as for moulding them by the diocesan authorities.

Key words: Diocese of Kielce; deanery; vicariate forane; decanal conferences; Church administration; pastoral work.

Translated by Tomasz Patkowski

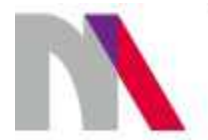

The preparation of the English version of Roczniki Humanistyczne (Annals of Arts) and its publication in electronic databases was financed under contract no. 836/P-DUN/2018 from the resources of the Minister of Science and Higher Education for the popularization of science. 